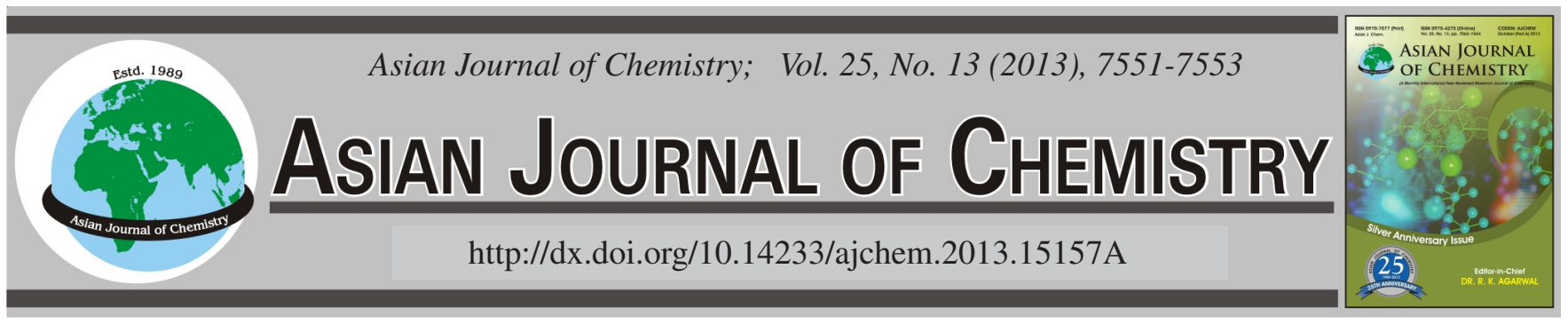

\title{
Antibacterial and Antifungal Activities of Bisbenzoylthiourea Compounds from Benzoyl Isothiocyanate and Diamines
}

Meng-Meng Zhao*, Xiu-Yan Dong, Gang Li, Yu-Hua Yang, Yu-Jie Zhang and Xiao-Qin Yang

School of Chemical and Biological Engineering, Lanzhou Jiaotong University, Lanzhou 730070, P.R. China

*Corresponding author: E-mail: zhaomm80@163.com

(Received: 15 January 2013;

Accepted: 1 July 2013)

AJC-13749

Five bisbenzoylthiourea compounds have been synthesized from benzoyl isothiocyanate and different diamines in $\mathrm{CH}_{2} \mathrm{Cl}_{2} \mathrm{medium}_{\mathrm{under}}$ solid-liquid phase transfer catalysis conditions. Structures of these compounds have been characterized by elemental analyses as well as IR and ${ }^{1} \mathrm{H}$ NMR spectroscopy. These compounds were tested for their antibacterial and antifungal activities. The results indicated most of the compounds have good antimicrobial activities, especially in against agriculture disease fungal.

Key Words: Bisbenzoylthiourea, Synthesis, Antibacterial and antifungal activity.

\section{INTRODUCTION}

As we know, thiourea compounds, especially acylthiourea compounds, are of great interest because of their varied biological activities such as herbicides, insecticides, plant-growth regulators, antifungal and pharmacodynamics ${ }^{1-4}$. Some thiourea compounds are prominent organic reaction catalyst in the metal-catalyzed asymmetric reduction of carbonyl compounds and carbonylative cyclization of $o$-hydroxyarylacetylenes $^{5-7}$. In recent years, with the rapid development of coordination chemistry and supramolecular chemistry, thiourea compounds are one of many important neutral receptors and their tendency to coordinate with metal ions ${ }^{8-13}$. Herein, in a novel series of bisbenzoylthioureas (3a-3e) have been synthesized and characterized by elemental analyses, IR and ${ }^{1} \mathrm{H}$ NMR spectroscopy, their antibacterial activities have also been studied.

\section{EXPERIMENTAL}

Benzoyl chloride, $o$-chlorobenzoyl chloride, 1,2-dibromoethane, 1,3-dibromopropane and polyethylene glycol-400 were purchased from Alfa Aesar and used without further purification. The other reagents and solvents were analytical grade reagents from Tianjin Chemical Reagent Factory. 1,2Bis(phthalimidooxy)ethane and 1,3-bis(phthalimidooxy)propane were synthesized according to a literature method ${ }^{14-}$ ${ }^{16}$. C, $\mathrm{H}$ and $\mathrm{N}$ analyses were carried out with a $\mathrm{GmbH}$ VariuoEL V3.00 automatic elemental analyzer. IR spectra in the range $4000-400 \mathrm{~cm}^{-1}$ were recorded on a VERTEX70 FT-
IR spectrophotometer using $\mathrm{KBr}$ pellets. The ${ }^{1} \mathrm{H}$ NMR spectra were recorded on a Mercury-400BB spectrometer at room temperature using $\mathrm{CDCl}_{3}$ as solvent. Melting points was measured by the use of a microscopic melting point apparatus made in Beijing Taike Instrument Limited Company and the thermometer was uncorrected.

The antimicrobial activity was determined using agar disc diffusion method by measuring the inhibition zone in $\mathrm{mm}$. The microbiology stains were obtained from China Center of Industrial Culture Collection, including 4 species of bacteria: Pseudomonas aeruginosa NKCCMRNK10.PAO1DrhlI and Escherichia coli ACCC11864 as gram-negative Obligate aerobes bacteria, Corynebacterium diphtheriae CCTCCAB2010172 and Staphylococcus aureus ACCC01331 as gram-positive facultative aerobic bacteria. 3 species of fungi: Gibberella sp. CICIMF0137, Pythium aphanidermatum ACCC36125 and Cochliobolus sativus ACCC30139 as against agricultural disease fungal. Ampicillin and nystatin were served as standard antibacterial and antifungal agents, respectively.

General procedure: Benzoyl chloride and its derivatives was treated with ammonium thiocyanate under the condition of solid-liquid phase transfer catalysis using PEG-400 as the catalyst to give the corresponding benzoyl isothiocyanates, without isolation, the obtained benzoyl isothiocyanates were treated with differet diamines to afford the title compounds 3a-3e in good-to-excellent yield ${ }^{17,18}$. Synthetic route to benzoylthiourea derivatives 3a-3d is shown in Fig. 1. All the synthesized compounds have been characterized by elemental analyses as well as IR and ${ }^{1} \mathrm{H}$ NMR spectroscopy (Tables 1 and 2). 


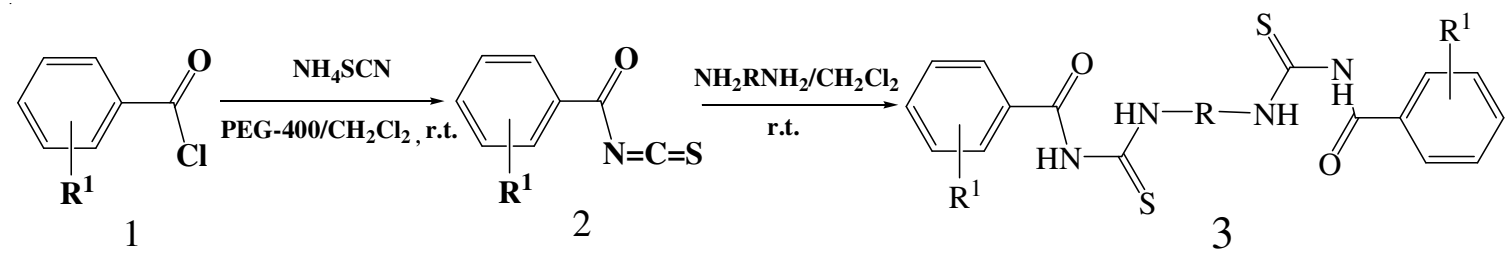

3a: $\mathrm{R}^{1}=\mathrm{H}, \mathrm{R}=-\mathrm{CH}_{2}-\mathrm{CH}_{2}$;

$3 b: \mathrm{R}^{1}=\mathrm{H}, \mathrm{R}=-\mathrm{CH}_{2}-\mathrm{CH}_{2}-\mathrm{CH}_{2}-\mathrm{CH}_{2}-$;

3c: $\mathrm{R}^{1}=2-\mathrm{Cl}, \mathrm{R}=-\mathrm{CH}_{2}-\mathrm{CH}_{2}-\mathrm{CH}_{2}-\mathrm{CH}_{2}-\mathrm{CH}_{2}-\mathrm{CH}_{2}$;

3d: $\mathrm{R}^{1}=\mathrm{H}, \mathrm{R}=-\mathrm{O}-\mathrm{CH}_{2}-\mathrm{CH}_{2}-\mathrm{O}-$;

3e: $\mathrm{R}^{1}=\mathrm{H}, \mathrm{R}=-\mathrm{O}-\mathrm{CH}_{2}-\mathrm{CH}_{2}-\mathrm{CH}_{2}-\mathrm{O}-$;

Fig. 1. Synthetic route to benzoylthiourea derivatives $\mathbf{3 a - 3 e}$

\begin{tabular}{|c|c|c|c|c|c|c|c|}
\hline \multirow{3}{*}{ Compound } & \multirow{3}{*}{ Colour } & \multirow{3}{*}{ m.p. $\left({ }^{\circ} \mathrm{C}\right)$} & \multirow{3}{*}{ Yield (\%) } & \multirow{3}{*}{ m.f. (m.w.) } & YNTHESIZED & POUNDS 3 & \\
\hline & & & & & \multicolumn{3}{|c|}{ Elemental analysis (\%): Found (calcd.) } \\
\hline & & & & & $\mathrm{C}$ & $\mathrm{H}$ & $\mathrm{N}$ \\
\hline 3a & Colourless & $214-215$ & 82.3 & $\mathrm{C}_{18} \mathrm{H}_{18} \mathrm{~N}_{4} \mathrm{O}_{2} \mathrm{~S}_{2}$ (386.49) & $55.90(55.94)$ & $4.59(4.69)$ & $14.28(14.50)$ \\
\hline $3 \mathbf{b}$ & Colourless & $196-198$ & 81.8 & $\mathrm{C}_{20} \mathrm{H}_{22} \mathrm{~N}_{4} \mathrm{O}_{2} \mathrm{~S}_{2}(414.54)$ & $57.91(57.95)$ & $5.47(5.35)$ & $13.36(13.52)$ \\
\hline $3 \mathbf{c}$ & Colourless & $176-178$ & 90.6 & $\mathrm{C}_{22} \mathrm{H}_{26} \mathrm{~N}_{4} \mathrm{O}_{2} \mathrm{~S}_{2}(442.6)$ & $59.86(59.70)$ & 5. $90(5.92)$ & $12.39(12.66)$ \\
\hline 3d & Colourless & $122-123$ & 65.6 & $\mathrm{C}_{18} \mathrm{H}_{18} \mathrm{~N}_{4} \mathrm{O}_{4} \mathrm{~S}_{2}(418.49)$ & $51.43(51.66)$ & $4.60(4.34)$ & $13.71(13.39)$ \\
\hline $3 e$ & Colourless & $117-118$ & 51.8 & $\mathrm{C}_{19} \mathrm{H}_{20} \mathrm{~N}_{4} \mathrm{O}_{4} \mathrm{~S}_{2}(432.52)$ & $52.62(52.76)$ & $4.95(4.66)$ & $13.23(12.95)$ \\
\hline
\end{tabular}

TABLE-2

IR AND ${ }^{1} \mathrm{H}-N M R$ SPECTRAL DATA OF SYNTHESIZED COMPOUNDS3a-3e

\begin{tabular}{|c|c|c|}
\hline Compound & $\operatorname{IR}\left(v, \mathrm{~cm}^{-1}\right)$ & ${ }^{1} \mathrm{HNMR}\left(\mathrm{DMSO}-d_{6}, \delta / \mathrm{ppm}\right)$ \\
\hline $\mathbf{3 a}$ & $3422,3234(\mathrm{NH}) ; 1668(\mathrm{C}=\mathrm{O}) ; 1158(\mathrm{C}=\mathrm{S})$ & $3.98\left(\mathrm{t}, 4 \mathrm{H}, \mathrm{CH}_{2}\right) ; 7.36-7.98\left(\mathrm{~m}, 10 \mathrm{H}, \mathrm{C}_{6} \mathrm{H}_{5}\right) ; 10.95(\mathrm{~s}, 2 \mathrm{H}, \mathrm{NH}) ; 11.31(\mathrm{~s}, 2 \mathrm{H}, \mathrm{NH})$. \\
\hline $3 \mathbf{b}$ & $3416,3222(\mathrm{NH}) ; 1672(\mathrm{C}=\mathrm{O}) ; 1146(\mathrm{C}=\mathrm{S})$ & $\begin{array}{l}1.70\left(\mathrm{t}, 4 \mathrm{H}, \mathrm{CH}_{2}\right) ; 3.68\left(\mathrm{t}, 4 \mathrm{H}, \mathrm{CH}_{2}\right) ; 7.45-7.92\left(\mathrm{~m}, 10 \mathrm{H}, \mathrm{C}_{6} \mathrm{H}_{5}\right) ; 10.91(\mathrm{~s}, 1 \mathrm{H}, \mathrm{NH}) ; \\
11.02(\mathrm{~s}, 1 \mathrm{H}, \mathrm{NH}) .\end{array}$ \\
\hline $3 c$ & 3243(NH); 1668(C=O); 1153(C=S) & $\begin{array}{l}1.45\left(\mathrm{t}, 4 \mathrm{H}, \mathrm{CH}_{2}\right) ; 1.65\left(\mathrm{t}, 4 \mathrm{H}, \mathrm{CH}_{2}\right) ; 3.60\left(\mathrm{t}, 4 \mathrm{H}, \mathrm{CH}_{2}\right) ; 7.45-7.93(\mathrm{~m}, 10 \mathrm{H} \text {, } \\
\left.\mathrm{C}_{6} \mathrm{H}_{5}\right) ; 10.89(\mathrm{~s}, 2 \mathrm{H}, \mathrm{NH}) ; 11.01(\mathrm{~s}, 2 \mathrm{H}, \mathrm{NH}) .\end{array}$ \\
\hline 3d & $3329,3175(\mathrm{NH}) ; 1680(\mathrm{C}=\mathrm{O}) ; 1178(\mathrm{C}=\mathrm{S})$ & $\begin{array}{l}4.50\left(\mathrm{~s}, 4 \mathrm{H}, \mathrm{CH}_{2}\right) ; 7.51(\mathrm{t}, J=10.2 \mathrm{~Hz}, 4 \mathrm{H}, \operatorname{ArH}) ; 7.61(\mathrm{~d}, J=10.2 \mathrm{~Hz}, 2 \mathrm{H}, \mathrm{ArH}) ; 7.83 \\
(\mathrm{~d}, J=10.8 \mathrm{~Hz}, 4 \mathrm{H}, \operatorname{ArH}) ; 8.93(\mathrm{~s}, 2 \mathrm{H}, \mathrm{HN}) ; 12.90(\mathrm{~s}, 2 \mathrm{H}, \mathrm{HN}) .\end{array}$ \\
\hline $3 \mathbf{e}$ & 3203(NH); 1677(C=O); $1177(\mathrm{C}=\mathrm{S})$ & $\begin{array}{l}2.18\left(\mathrm{~d}, J=8.8 \mathrm{~Hz}, 2 \mathrm{H}, \mathrm{CH}_{2}\right) ; 4.40\left(\mathrm{t}, J=8.2 \mathrm{~Hz}, 4 \mathrm{H}, \mathrm{CH}_{2}\right) ; 7.52(\mathrm{t}, J=10.2 \mathrm{~Hz}, 4 \mathrm{H} \text {, } \\
\operatorname{ArH}) ; 7.62(\mathrm{~d}, J=9.2 \mathrm{~Hz}, 2 \mathrm{H}, \mathrm{ArH}) ; 7.85(\mathrm{~d}, J=9.2 \mathrm{~Hz}, 4 \mathrm{H}, \operatorname{ArH}) ; 8.90(\mathrm{~s}, 2 \mathrm{H}, \mathrm{HN}) ; \\
12.78(\mathrm{~s}, 2 \mathrm{H}, \mathrm{HN}) .\end{array}$ \\
\hline
\end{tabular}

Synthesis of N, $N^{\prime}-(1,4-$ tetramethylene)bisbenzoylthiourea (3a), N,N'-(1,4-tetramethylene)bisbenzoylthiourea (3b) and N, N'-(1,6-hexamethylene)bisbenzoylthiourea (3c): $1.41 \mathrm{~g}(0.01 \mathrm{~mol})$ of benzoyl chloride was reacted with $1.15 \mathrm{~g}$ $(0.015 \mathrm{~mol})$ of ammonium thiocyanate in $25 \mathrm{~mL}$ of $\mathrm{CH}_{2} \mathrm{Cl}_{2}$ under solid-liquid phase transfer catalysis conditions, using $0.18 \mathrm{~g}$ of $3 \%$ polyethylene glycol- 400 as the catalyst, to give the corresponding benzoyl isothiocyanate after stirring for $1 \mathrm{~h}$ at the room temperature, a white pricipatate was formed and the white solution turned to yellow, filtered and washed with $\mathrm{CH}_{2} \mathrm{Cl}_{2}$, which was reacted with a $\mathrm{CH}_{2} \mathrm{Cl}_{2}(15 \mathrm{~mL})$ solution of $0.0045 \mathrm{~mol}$ of diamines (ethanediamine/1,4-butanediamine/ 1,6-hexamethylendiamine) at the room temperature, after stirring for $2.5 \mathrm{~h}$. The solid isolated was separated from the liquid phase by filtration, washed successively with $\mathrm{CH}_{2} \mathrm{Cl}_{2}$ and $\mathrm{H}_{2} \mathrm{O}$, respectively, the product was dried under reduced pressure and purified with recrystallization from DMF to obtain the title compound $\mathbf{3 a - 3 c}$.
Synthesis of N,N'-(ethylenedioxy)bisbenzoylthiourea (3d) and $N, N^{\prime}-(1,3-$ propylenedioxy)bisbenzoylthiourea (3e): Benzoyl chloride $(0.72 \mathrm{~g}, 0.005 \mathrm{~mol})$ was reacted with ammonium thiocyanate $(0.57 \mathrm{~g}, 0.0075 \mathrm{~mol})$ in $\mathrm{CH}_{2} \mathrm{Cl}_{2}(15 \mathrm{~mL})$ solution under soild-liquid phase transfer catalysis, using polyethylene glycol-400 (0.09 g) as the catalyst, to give a $\mathrm{CH}_{2} \mathrm{Cl}_{2}$ solution of benzoyl isothiocyanate, which was reacted with a $\mathrm{CH}_{2} \mathrm{Cl}_{2}(15 \mathrm{~mL})$ solution of $0.0025 \mathrm{~mol}$ of diamines (1,2-bis(amineoxy)ethane ${ }^{19-22} / 1,3-b i s\left(\right.$ amineoxy)propane $\left.{ }^{22-24}\right)$ at the room temperature, after stirring for $4 \mathrm{~h}$. The solid isolated was separated from the liquid phase by filtration, washed successively with $\mathrm{H}_{2} \mathrm{O}$ and $\mathrm{CH}_{2} \mathrm{Cl}_{2}$, respectively, the product was dried under reduced pressure to obtain the title compounds (3d and 3e).

Antimicrobial activity: All the synthesized compounds were evaluated in vitro for their antibacterial and antifungal activities. nutrient agar and sabourd's medium were used to culture bacteria and fungal, respectively. The hot nutrient agar 


\begin{tabular}{|c|c|c|c|c|c|c|c|}
\hline \multicolumn{8}{|c|}{$\begin{array}{c}\text { TABLE-3 } \\
\text { RESULTS OF ANTIMICROBIAL ACTIVITY OF SYNTHESIZED COMPOUNDS 3a-3e }\end{array}$} \\
\hline \multirow[b]{2}{*}{ Compound } & \multicolumn{7}{|c|}{ Diameter of zone of inhibition (mm) } \\
\hline & $\begin{array}{l}\text { Pseudomonas } \\
\text { aeruginosa }\end{array}$ & $\begin{array}{l}\text { Escherichia } \\
\text { coli }\end{array}$ & $\begin{array}{l}\text { Corynebacterium } \\
\text { diphtheriae }\end{array}$ & $\begin{array}{l}\text { Staphylococcus } \\
\text { aureus }\end{array}$ & $\begin{array}{l}\text { Gibberella } \\
\text { sp. }\end{array}$ & $\begin{array}{c}\text { Pythium } \\
\text { aphanidermatum }\end{array}$ & $\begin{array}{l}\text { Cochliobolus } \\
\text { sativus }\end{array}$ \\
\hline $3 a$ & $3.1 \pm 0.1$ & $5.4 \pm 0.15$ & $6.8 \pm 0.25$ & $5.9 \pm 0.2$ & $8.1 \pm 0.3$ & $6.3 \pm 0.2$ & $8.2 \pm 0.1$ \\
\hline 3b & - & - & $4.3 \pm 0.2$ & $5.6 \pm 0.15$ & $7.9 \pm 0.3$ & - & $8.4 \pm 0.35$ \\
\hline $3 c$ & $5.4 \pm 0.15$ & $6.9 \pm 0.25$ & $7.7 \pm 0.15$ & $6.2 \pm 0.2$ & $8.8 \pm 0.2$ & $9.3 \pm 0.4$ & $8.9 \pm 0.1$ \\
\hline 3d & $14.8 \pm 0.6$ & $11.9 \pm 0.45$ & $15.1 \pm 0.5$ & $12.1 \pm 0.3$ & $17.6 \pm 0.7$ & $16.8 \pm 0.5$ & $17.5 \pm 0.6$ \\
\hline $3 e$ & $10.4 \pm 0.35$ & $8.9 \pm 0.3$ & $11.2 \pm 0.5$ & $8.6 \pm 0.4$ & $13.1 \pm 0.4$ & $15.6 \pm 0.3$ & $14.3 \pm 0.6$ \\
\hline Ampicillin & $16 \pm 0.25$ & $15.9 \pm 0.7$ & $13.7 \pm 0.4$ & $13.6 \pm 0.5$ & - & - & - \\
\hline Nystatin & - & - & - & - & $15.4 \pm 0.3$ & $18.1 \pm 0.6$ & $17.3 \pm 0.5$ \\
\hline
\end{tabular}

and sabourd's medium solution was poured into sterilized petridishes and allowed to attain room temperature. Seed layer medium which contains the previously grown subculture was lawned into the Petri dishes. Cups were made using sterile borer of $5 \mathrm{~mm}$ diameter. To these cups $0.5 \mathrm{~mL}$ of the drug solution $(50 \mu \mathrm{g} / \mathrm{mL})$, standard solution were added and allowed to cool for $1 \mathrm{~h}$ to facilitate diffusion. The plate was incubated at $37^{\circ} \mathrm{C}$ for $48 \mathrm{~h}$. Zone of inhibition around wells were measured. All tests were repeated three times to confirm the results. The results are showed in Table- 3 .

\section{RESULTS AND DISCUSSION}

A series of bisbenzoylthiourea compounds 3a-3e have been synthesized with good yields and the structures are confirmed by elemental analyses, IR spectra and ${ }^{1} \mathrm{H}$ NMR data.

All the synthesized compounds were tested for their antimicrobial activities and 7 species of microbial have been choosen. Because two classes of the compounds synthesized above (3d and $\mathbf{3 e}$ ) were oxime compounds and they were reported as oxygen eliminating agent, so they were tested by two obligate aerobes bacteria and two facultative aerobic bacteria to prove their oxygen eliminating activities. Acylthiourea compounds also reported varied biological activities especially in the aspect of agricultural disease prevention and treatment, so they were tested by 3 species of commom agricultural disease fungal to prove their antifungal activities. The results presented: compound $\mathbf{3 d}$ showed the highest antibacterial and antifungal activities and close to the standard drug. For some bacteria and fungal, compound 3d even have higher antimicrobial activities than the standard drugs like the experiment of Corynebacterium diphtheria, Gibberella sp and Cochliobolus sativus. Compounds $\mathbf{3 e}$ and $\mathbf{3 c}$ also possess higher antibacterial and antifungal activities. Compounds $\mathbf{3 d}$ and $\mathbf{3 e}$ were shown higher inhibition on the two Obligate aerobes bacteria and lower inhibition on the two facultative aerobic bacteria because of their oxygen eliminating activities. At the concentration of $50 \mu \mathrm{g} / \mathrm{mL}$, compound $\mathbf{3 b}$ have no inhibition on gram-negative bacteria like the experiment of Pseudomonas aeruginosa and Escherichia coli, it possess the lowest antibacterial and antifungal activities as compared to the other compounds. In a word, the antimicrobial experiments had indicated most of the synthesized compounds have shown good antibacterial and antifungal activities as compared to their standard drugs, but the antifungal activity is more prominent. So the bright prospects of the compounds synthesized above in against agricultural disease fungal and the potential of antimicrobial have been brought out.

\section{REFERENCES}

1. A. Jurasek, P. Safer and V. Zvak, Chem. Pap., 41, 693 (1987).

2. S.G. Teoh, S.H. Ang, H.K. Fun and C.-W. Ong, J. Organomet. Chem., 580, 17 (1999).

3. H. Arslan, N. Duran, N.O. Sahin and N. Kulcu, Asian J. Chem., 18, 1710 (2006).

4. R. Campo, J.J. Criado, E. Garcia, M.R. Hermosa, A. Jiménez-Sánchez, J.L. Manzano, E. Monte, E. Rodríguez-Fernández and F. Sanz, J. Inorg. Biochem., 89, 74 (2002).

5. Y. Nan, H. Miao and Z. Yang, Org. Lett., 2, 297 (2000).

6. J.A.J. Breuzard, M.L. Tommasino, F. Toucard, M. Lemaire and M.C. Bonnet, J. Mol. Catal. A: Chem., 156, 223 (2000).

7. F. Touchard, F. Fache and M. Lemaire, Tetrahedron: Asymm., 8, 3319 (1997).

8. P. Buhlmann, S. Nishizawa, K.P. Xiao and Y. Umezawa, Tetrahedon, 53, 1647 (1997).

9. Y.M. Zhang, W.X. Xu, Y.Q. Zhou, H. Yao and T.-B. Wei, Acta Chim. Sin., 64, 79 (2006).

10. J. Valdés-Martínez, S. Hernández-Ortega, M. Rubio, D.T. Li, J.K. Swearingen, W. Kaminsky, D.R. Kelman and D.X. West, J. Chem. Crystallogr., 34, 533 (2004).

11. Y.M. Zhang, T.B. Wei, L, Xian and L.M. Gao, Phosphorus, Sulfur Silicon Rel. Elem., 179, 2007 (2004).

12. Y.M. Zhang, L. Xian, T.B. Wei and K.B. Yu, J. Chem. Res., 798 (2003).

13. E. Guillon, I. DeÂchamps-Olivier and J.P. Barbier, Polyhedron, 17, 3255 (1998).

14. W.K. Dong, Y.X. Sun, S.J. Xing, Y. Wang and X.H. Gao, Z. Naturforsch., 67b, 197 (2012).

15. W.K. Dong, J.F. Tong, Y.X. Sun, S.S. Gong and L. Li, Synth. React. Inorg. Met.-Org. Nano-Met. Chem., 41, 155 (2011).

16. W.K. Dong and J.G. Duan, J. Coord. Chem., 61, 781 (2007).

17. Y.M. Zhang, L. Xian and T.B. Wei, Acta Cryst., C59, m473 (2003).

18. W.K. Dong, X.Q. Yang. L.Q. Chai, Y.Q. Tian and J.H. Feng, Phosphorus, Sulfur Silicon Rel. Elem., 183, 1181 (2008).

19. S. Akine, T. Taniguchi and T. Nabeshima, Angew. Chem., Int. Ed., 41, 4670 (2002).

20. W.K. Dong, G. Wang, S.S. Gong, J.F. Tong, Y.X. Sun and X.H. Gao, Transition Met. Chem., 37, 271 (2012).

21. W.K. Dong, Y.X. Sun, X.N. He J.F. Tong and J.C. Wu, Spectrochim. Acta A, 76, 476 (2010).

22. W.K. Dong, Y.X. Sun, Y.P. Zhang, L. Li, X.N. He and X.L. Tang, Inorg. Chim. Acta, 362, 117 (2009).

23. W.K. Dong, X.N. He, H.B. Yan, Z.W. Lv, X. Chen, C.Y. Zhao and X.L. Tang, Polyhedron, 28, 1419 (2009).

24. W.K. Dong, J.G. Duan, Y.H. Guan, J.Y. Shi and C.Y. Zhao, Inorg. Chim. Acta, 362, 1129 (2009). 